\title{
POJĘCIE ŚWIATOPOGLĄDU EKUMENICZNEGO I JEGO ZNACZENIE DLA EKUMENIZMU
}

W poszukiwaniach teologów ekumenistów, a więc teologów, którzy na różne sposoby i w różnym stopniu akceptują ideę dążenia do jedności chrześcijan, zaskakująco skąpo mówi się o pojęciu „światopoglądu ekumenicznego". W teologicznoekumenicznej refleksji powiedziano już wiele o tożsamości wyznaniowej i tożsamości ekumenicznej, o ruchu ekumenicznym, o duchowości ekumenicznej, o ekumenicznym dialogu, jego recepcji i jego hermeneutyce. Pojęcia te mogą być uznane za słowa kluczowe ekumenizmu ujmowanego jako subdyscyplina teologii. Dowodzą tego teologicznoekumeniczna literatura z ostatnich lat, jak również analiza tematów licznych ekumenicznych konferencji w minionej dekadzie. Jednak odnalezienie artykułu bądź referatu rozważającego pojęcie światoglądu określanego przez ekumenizm jest zadaniem zdecydowanie trudniejszym.

Taki brak jest o tyle zastanawiający, że termin ten posiada potencjał, którego rozwinięcie może znacząco wzbogacić dążenia ekumeniczne. Chrześcijanie gromadzący się we wspólnych działaniach, które na różne sposoby wyrażają dążenia do jedności, odkrywają często, że ich widzenie świata i postawa wobec rzeczywistości są podobne, pomimo różnic w doktrynie teologicznej czy w tradycjach liturgicznych. Wspólnota idei jest tym silniej odczuwana, im bardziej kontrastuje z sekularyzującym się społeczeństwem z jednej strony i z zamykającymi się we własnych tożsamościach wyznaniowych macierzystymi środowiskami kościelnymi. Ta wzajemność myśli 
i identyfikacji z ekumeniczną ideą i z ekumenicznym środowiskiem, które przecież z kolei poczuwa się do reprezentacji całego chrześcijaństwa, mogłaby być rozumiana właśnie jako podzielany przez swych uczestników światopogląd ekumeniczny. Pojęcie to jawi się jako uzupełniające katalog słów kluczowych organizujących refleksję na temat ekumenizmu, zwracając uwagę zwłaszcza na indywidualny aspekt samego ekumenizmu. Chodzi tu przede wszystkim o fakt, że ruch ekumeniczny jest tworzony przez konkretne jednostki, pewnego rodzaju liderów, którzy odkrywając w sobie zdolności i kompetencje do działania na rzecz jedności chrześcijan, spoglądają na otaczającą rzeczywistość w perspektywie właśnie światopoglądu ekumenicznego.

Artykuł dąży do odpowiedzi na pytanie, jak ten światopogląd ekumeniczny można zdefiniować w świetle teoretycznej dyskusji nad światopoglądem oraz stara się ustalić jak ekumenizm jako taki determinuje światopogląd danej jednostki. W formułowaniu odpowiedzi na tak postawione pytania badawcze przeprowadzono syntetyczną prezentację fundamentalnych koncepcji dotyczących światopoglądu, którą zestawiono ze zwięzłą analizą dokumentów oraz opracowań na temat ekumenizmu i jego roli w formułowaniu obrazu świata.

\section{ZNACZENIE I POTENCJAL POJECIA ŚWIATOPOGLĄDU}

Zdefiniowanie światopoglądu jest dość kłopotliwe. Po pierwsze bowiem, pojęcie to należy do tego rodzaju słów, którymi posługujemy się bezwiednie, zakładając ich jakby automatyczne zrozumienie. O ile w czasie jego zaistnienia w systematycznej tradycji filozoficznej posiadało wyraźnie nakreślone granice przez poszczególnych autorów, o tyle dzisiaj jest powszechnie używane w języku potocznym, w którym przypisuje mu się odmienne niekiedy znaczenia. Doświadczana często w języku nieumiejętność rozróżnienia pomiędzy światopoglądem, ideologią i filozofią jest tego najlepszym przykładem. Po drugie, światopogląd jest definiowany odmiennie w zależności od przyjętej podstawy epistemologicznej i aksjologicznej. Podobnie 
jak w przypadku innych terminów w naukach społecznych i humanistycznych nie jest ,pojęciem przeźroczystym”, wolnym od „semantycznej polifonii”'.

Prowadzi to do mnogości definicji i skazuje kolejnych jego interpretatorów albo na żmudną i często w kontekście zamierzenia niepotrzebną historyczną i systematyczną analizę rozwoju tego pojęcia, bądź też na selektywne przyjęcie jakiejś definicji uznanej za najbardziej adekwatną, bądź na intencjonalną rezygnację ze ścisłego zdefiniowania na rzecz opisowego przedstawienia zagadnień związanych ze światopoglądem, albo wreszcie na sformułowanie własnego rozumienia jego znaczenia.

Po trzecie zaś, współczesność, obdarzana często etykietami ponowoczesności, jest również wiązana z kryzysem znaczenia światopoglądu. Dotyczy to przede wszystkim jego roli dla konkretnej jednostki. Niewątpliwy obecnie relatywizm epistemologiczny i etyczny powoduje również, że dzisiejszemu człowiekowi w kulturze zachodniej trudno jest uniknąć sprzecznych, albo wręcz wykluczających się czynników, które tworzą jego światopogląd. W konsekwencji więc pojęcie to traci swoją socjologiczną oraz psychologiczną funkcję i to nie tylko dlatego, że odpowiedź na pytanie o światopogląd zawsze była trudna i wymagała znajomości pewnego aparatu pojęciowego. Również dlatego, że wbrew licznym usiłowaniom tych, którym zależy na harmonijnym rozwoju społeczeństwa i jednostki, najważniejsze źródła światopoglądu, a więc nauka (rozumiana jako nauki ścisłe), filozofia rozumiana jako pytanie o rzeczywistość, religia i kultura zdają się coraz bardziej rozchodzić. Trzeba tu powiedzieć, że teza ta łatwo może znaleźć swych krytyków, którzy będą sięgać po kontrargumenty zgodnie z którymi nauka, religia czy sztuka harmonijnie współegzystują ze sobą. Kluczowe jest tu jednak pytanie o zasadność rozciągania takich sądów na wszystkich przedstawicieli nauki czy

1 J. Cieciuch, Czym jest światopoglad? Filozoficzny kontekst psychologicznego pojęcia, „Psychologia Rozwojowa”10/2(2005), s. 149. 
religii ${ }^{2}$. Zwłaszcza nauka może być dziś posądzana o zawłaszczanie całego obszaru znaczeń, które decydują o czyimś światopoglądzie i o odbieranie innym źródłom wiarygodności i rzetelności. W konsekwencji człowiek współczesny poddawany jest niekończącym się przejawom toczącego się na zewnątrz konfliktu teoriopoznawczego i aksjologicznego, który naraża jego światopogląd na permanentną niestabilność i zniechęca do świadomego stawiania związanych z nim pytań. Ponadto, konflikt ten rodzi przeciwstawne sobie i wykluczające się światopoglądy, które wciąż stykają się ze sobą w życiu społecznym.

Niezależnie od nakreślonych powyżej kwestii, konieczne jest przypomnienie podstawowych definicji światopoglądu, zarówno w perspektywie historycznej jak i analitycznej. Pojęcie światopoglądu wywodzi się z dziewiętnastowiecznej niemieckiej filozofii idealistycznej oraz romantycznej. Po raz pierwszy, choć incydentalnie, zostało użyte przez Kanta, który odnosił je do sposobu, w jaki jednostka postrzega całość zjawisk składających się na rzeczywistość. Hegel ujmował je jako szczegółową manifestację całej wiedzy świata, wyrażanej w historycznych systemach filozoficznych. Światopogląd definiowali również Johann Gottlieb Fichte, Wilhelm von Humboldt oraz Friedrich Wilhelm von Scheling i dalej szereg przedstawicieli różnych dyscyplin humanistycznych i społecznych. Poglądowy przegląd takich różnych podejść do pojęcia światopoglądu nakreśla James Olthuis. Wspomina Humboldta i Benjamina Lee Whorfa, których można byłoby określić jako reprezentantów podejścia lingwistycznego i którzy przyjmowali, że światopogląd jest determinowany przez język. W sferze nauki odwołuje się do Michala Polanyi’ego, którego słynna książka „Tacit Dimension” stawiała wyzwanie dominującemu modelowi fizyczno-empirycznemu (Polanyi głosił, że „powinienem rozważyć ludzką wiedzę wychodząc od założenia, iż wiemy więcej, niż możemy to powiedzieć" i że taka milcząca wiedza - tradycja, odziedziczone praktyki, sugerowane wartości czy przesądy

${ }^{2}$ G. Stäuble, Wissenschaftliche Weltanschauungen, „Aufklärung und Kritik Zeitschrift für freies Denken und humanistische Philosophie” 1/2015, s. 188. 
- stanowi ważny komponent poznania naukowego) $)^{3}$. Dalej, również w perspektywie nauki, Olthuis przywołuje Thomasa Kuhna i jego nowoczesną koncepcję paradygmatów jako ekranów, które pozwalają pewne zjawiska rozważać jako prawomocne przedmioty badania, a inne wykluczać (Kuhn definiuje paradygmaty jako ogólnie uznane osiągnięcia naukowe, które w danym czasie dostarczają społeczności praktycznych modeli problemów i rozwiązań) ${ }^{4}$. W sferze psychologii odnosi się do badań, które jaskrawo ukazały fundamentalne znaczenie więzi między rodzicami i dziećmi dla życia i sposobu myślenia w życiu dorosłym. W przestrzeni teologicznej wspomina o wpływie teologii liberalnej, która zmieniła akcenty z ortodoksji, a więc prawidłowego myślenia, na ortopraksję, a więc prawidłowe działanie. Wreszcie, przywołuje rosnące znaczenie myślenia w kategoriach socjo-biologicznych, które pierwotne determinanty ludzkiego działania dostrzegają nie tyle w wierze, kontekście społeczno-kulturowym bądź nieświadomości, ale w czynnikach genetycznych i biologicznych ${ }^{5}$. Do przeglądu poczynionego przez Olthuisa można byłoby dodać antynomiczne rozróżnienie na światopogląd naukowy i światopogląd religijny, które porządkowało debaty na temat tego pojęcia w czasach istnienia bloku politycznego inspirowanego marksizmem-leninizmem i które do dziś może służyć za podstawowy wzór kategoryzowania danego światopoglądu.

W kontekście tematu niniejszego opracowania należy jednak zwrócić szczególną uwagę na dwóch autorów, z których pierwszy jest teologiem, ale istotnym również dla historii filozofii, a drugi filozofem, ale z silnym nakierowaniem na teologię i niekiedy systematyzowany jako przedstawiciel protestanckiej teologii liberalnej. Pierwszy z nich to Friedrich Daniel Schleiermacher, drugi zaś to

3 A. Sen, Foreword, w: M. Polanyi, The Tacit Dimension, Chicago: The University of Chicago Press 2009, s. 5.

4 T. S. Kuhn, The Structure of Scientific Revolutions, Chicago: The University of Chicago Press 1970, s. viii.

5 J.H. Olthuis, On Worldviews, w: P. Marshall, S. Griffioen, R. J. Mouw (red.), Stained Glass: Worldviews and Social Science, Lanham: University Press of America 1983, s. $27 n$. 
Wilhelm Dilthey. Schleiermacher, prekursor teologicznego liberalizmu, określony przez Karla Bartha „ojcem teologii liberalnej”, ujmował światopogląd w perspektywie własnej, głęboko indywidualistycznej filozofii i subiektywizmu religijnego: „Światogląd jest rezultatem spekulatywnej wiedzy naukowej i naukowego ujmowania historii. Zakłada najwyższe samo-działanie ludzkiego ducha. Ale jednocześnie jest w on w tym rozwoju z punktu początkowego, w którym ukazano nam znaczenie jedyności, do tego punktu, w którym się uformował, zintegrowaną całością a wciąż nowe wrażenia tworzą jego fundamenty"6. Dilthey, uznany za autora, który ma największy wkład w formułowanie teorii światopoglądu, definiował je w perspektywie rozwijanej przez siebie filozofii życia (warto nadmienić, że był twórcą również biografii Schleiermachera). W jego ocenie, każde ludzkie działanie musi mieć fundament w pierwotnym założeniu jakim jest życie jako takie. Niemiecki filozof przyjmuje więc za podstawę sferę wyprzedzającą i wykraczającą poza koncepcyjne i rozumowe schematy, za pomocą których człowiek (a przynajmniej osoba przynależąca do kultury zachodniej) próbuje porządkować i kategoryzować rzeczywistość. Sfera ta, zamykająca się w pomyślanym przez Diltheya pojęciu życia, zawsze będzie wymykać się totalnemu usystematyzowaniu. „Życie posiada u Diltheya zdecydowany prymat, ze względu na swoją «niezgłębioność» (Unergründlichkeit), a także ze względu na fakt, że istota ludzka nie potrafi jak dotąd nad nim zapanować w całkowitym stopniu"?.

Światopogląd dla Diltheya zasadza się więc na takiej właśnie koncepcji życia. Jest to po prostu sposób, w jaki życie (można byłoby dodać, iż w jednostkowej manifestacji jako poszczególnej jednostki ludzkiej) interpretuje zjawiska otaczającej go rzeczywistości, ujmując je w jakąś całość czy w jakiś system. „Światopogląd to nic innego,

${ }^{6}$ H. Leisegang, Einführung in die Philosophie, Berlin-New York: Walter de Gruyter 1973, s. 122.

${ }^{7}$ M. Markowska, Interpretacja jako rozumienie w ujęciu Wilhelma Diltheya, „Czasopismo Filozoficzne” 2/2007, s. 58n. Warto tutaj wspomnieć, że pojęcie Unergründlichkeit zakorzenione jest w średniowiecznej literaturze mistycznej. 
jak sposób interpretowania świata, ujmowania jego przejawów w specyficzny sposób zespolony w całość, dla której dominujący jest jeden element: religia, poezja, nauka itd"8. W konsekwencji więc dla Diltheya światopogląd będzie refleksyjnym odbiciem życia danej osoby w jej wszelakich uwarunkowaniach osobowościowych, kulturowych, społecznych, historycznych, geograficznych itd. Jednostka, w procesie tworzenia własnego światopoglądu, a więc interpretowania i rozumienia rzeczywistości, opiera się na trzech sklasyfikowanych przez niemieckiego autora źródłach tego poznania - na intelekcie, woli i czuciu. Sposób w jaki odbiera świat w którym żyje, zależy od tego, które ze źródeł jest dla niej najważniejsze. Taki psychologiczny mechanizm decyduje o stworzonej przez niemieckiego badacza typologii światopoglądu. Podsumowaniem koncepcji Diltheya (tak określonym przez niego samego) może być akapit z fundamentalnej dla teorii światopoglądu książki „Typy światopoglądów i ich kształtowanie w systemach metafizycznych" (Die Typen der Weltanschauung und ihre Ausbildung in den metaphysischen Systemen): „Światopoglądy nie są rezultatami myślenia. Nie wyłaniają się z gołej woli poznania. Ujmowanie rzeczywistości jest ważnym momentem w ich kształtowaniu się, ale nie jedynym. Światopoglądy wychodzą z postaw życiowych, z życiowego doświadczenia, ze struktur naszej totalności psychicznej. Wznoszenie życia do świadomości w poznaniu rzeczywistości, uczczeniu życia i kierowaniu woli jest żmudną i trudną pracą, której ludzkość dokonała w rozwoju oglądu życia"9.

8 Ibid., s. 72.

9 „Die Weltanschauungen sind nicht Erzeugnisse des Denkens. Sie entstehen nicht aus dem bloßen Willen des Erkennens. Die Auffassung der Wirklichkeit ist ein wichtiges Moment in ihrer Gestaltung, aber doch nur eines. Weltanschauungen gehen aus dem Lebensverhalten, der Lebenserfahrung, der Struktur unserer psychischen Totalität hervor. Die Erhebung des Lebens zum Bewußtsein in Wirklichkeitserkenntnis, Lebenswürdigung und Willensleistung ist die langsame und schwere Arbeit, welche die Menschheit in der Entwicklung der Lebensanschauungen geleistet hat". Zob. w: W. Dilthey, B. Groethuysen, Weltanschauungslehre. Abhandlungen zur Philosophie der Philosophie, Göttingen: Vandenhoeck \& Ruprecht 1991, s. 84. 


\section{II. ŚWIATOPOGLĄD A FILOZOFIA}

Spojrzenie na koncepcję Schleiermachera, a przede wszystkim Diltheya, zwraca uwagę na bardzo istotny fakt związany z dziewiętnastowiecznym rozwojem filozofii, kultury i społeczeństwa. Jest to mianowicie epoka, w której jednostka odkrywa możliwości koncentrancji na sobie, na swoich doświadczeniach. Odnosi się to przede wszystkim do epoki romantyzmu, w której, jak zauważa Colin Campbell, to indywidualny człowiek i jego przeżycia stają się centrum rzeczywistości; istotą jest skupienie się na własnym szczęściu $^{10}$. W takiej perspektywie łatwiej zrozumieć znaczenie, jakie przypisywane jest światopoglądowi. Zastępuje on bowiem do pewnego stopnia filozofię naukową, która podlega coraz większemu rozbiciu na poszczególne podejścia i reintegruje niejako źródła poznania, ale już na poziomie jednostki.

Relacja między filozofią i światopoglądem jest zresztą pełna styczności, które bądź powodują zamieszanie w uzgadnianiu zakresów znaczeń obu, bądź generują konflikt między nimi powodowany lękiem przed nachodzeniem na siebie. W gruncie rzeczy bowiem zarówno światopogląd, jak i filozofia dążą do odpowiedzi na fundamentalne pytania: Kim jestem? Czym jest rzeczywistość? Jakie jest znaczenie ludzkiego życia?

Interesujący przyczynek do rozumienia pojęcia światopoglądu dostarcza sformułowana przez Alberta Woltersa typologia przedstawiająca pięć typów zależności pomiędzy filozofią a światopoglądem. Warto wspomnieć, że schemat ten mocno przypomina słynne określene rodzajów zależności kultury i chrześcijaństwa wyróżnione przez Richarda Niebuhra, tym bardziej, że obaj autorzy są protestanckimi teologami.

Pierwszy typ opisywany jest wyrażeniem ,światogląd odrzuca filozofię" (worldview repels philosophy). Tak określona relacja charakteryzuje się nieuchronnym napięciem pomiędzy teoretyczną

${ }^{10}$ C. Campbell, The Romantic Ethic and the Spirit of Modern Consumerism, Oxford: Blackwell 1987, s. 78. 
filozofią a egzystencjalnym światopoglądem. Nie musi ono jednak być rozładowywane czy rozwiązywane, zarówno bowiem filozofia, jak i światopogląd są konieczne i uprawnione. Taki typ relacji jest reprezentowany przez egzystencjalizm (Wolters przywołuje to Kierkegaarda). Drugi rodzaj określany jest frazą ,światopogląd wieńczy filozofię" (worldview crowns philosophy). Światopogląd jest w niej nie tyle różny od filozofii, ale stanowi jej najwyższą manifestację. Celem filozofii jest mierzyć się z najważniejszymi pytaniami o sens i wartości i musi to ona czynić na poziomie światopoglądu. Trzeci model charakteryzowany jest wyrażeniem „światopogląd otacza filozofię" (worldview flanks philosophy). W tym typie filozofia i światopogląd muszą być radykalnie rozdzielane. Żadna pozycja światopoglądu nie może uzasadniać jego pomieszania z filozofią, albo też naruszania jej neutralności, również aksjologicznej. Jak zauważa Wolters, ten typ okazał się bardzo wpływowy, przez Heinricha Rickerta bowiem oddziałał na koncepcje światopoglądu formułowane przerz Edmunda Husserla, Maxa Webera czy Martina Heideggera. Czwarta figura ilustrowana jest frazą ,światopogląd kształtuje filozofię" (worldview yields philosophy). Filozofia nie tworzy światopoglądu, ale raczej jest przez światopogląd kształtowana i wyrażana. Z takim typem relacji utożsamiał się Dilthey. Wreszcie, piąty typ ujmowany jest zwrotem „światopogląd zrównywany jest z filozofią" (worldview equals philosophy). Oznacza całkowite utożsamienie światopoglądu i filozofii. Ten pierwszy jest po prostu sprowadzany do naukowego poznania filozoficznego podziela roszczenia filozofii do racjonalności i uniwersalnej prawomocności. Zdaniem Woltersa taki model był prezentowany przez Engelsa i obowiązywał jako standard w państwach, których ideologiczną dominantę stanowił marksizm-leninizm ${ }^{11}$.

Podsumowując krótkie rozważania dotyczące istoty pojęcia światopoglądu warto podać jeszcze definicję Antoniego Stępnia, formułowaną, jak można podejrzewać, w duchu Diltheya: „Światopogląd to

11 A.M. Wolters, On The Idea of Worldview and Its Relation to Philosophy, w: Marshall, Griffioen, Mouw (red.), Stained Glass: Worldviews and Social Science, tamże, s. 15 n. 
zespół przekonań i postaw, który to zespół w oczach jego wyznawcy czy zwolennika stanowi spójny, całościowy obraz rzeczywistości, porządkujący postępowanie wzglądem siebie i otoczenia"12. Określenie to w szczególny sposób może pomóc zrozumieniu, na czym polega światopogląd kształtowany ekumenicznie.

\section{EKUMENIZM JAKO CZYNNIK ŚWIATOPOGLĄDOWOTWÓRCZY}

Powyższe rozważania na temat pojęcia światopoglądu miały na celu zaakcentowanie jego znaczenia dla każdego człowieka. Dyskusja nad nim przypomina zresztą dyskusję nad tożsamością, tak żywą we współczesnej nauce społecznej. Światopogląd w swym podstawowym zdefiniowaniu, ujmującym go jako całość spostrzeżeń, przekonań i stosunków odnoszących się do otaczającej nas rzeczywistości, wciąż może odgrywać kluczową rolę w życiu jednostki i społeczeństwa. Rozumiany jako konstrukt myślowy, który zbudowany jest z zinterpretowanych i zinternalizowanych przez daną jednostkę odpowiedzi na fundamentalne pytania o świat, określa w ten sposób również naszą postawę wobec świata. Dlatego też pojęcie to wciąż może być ważnym narzędziem zarówno w kształtowaniu ujęcia rzeczywistości, jak i w określaniu postaw życiowych danych jednostek.

Aby właściwie zrozumieć termin światopoglądu ekumenicznego należy przede wszystkim zdefiniować słowo „ekumenizm”. Rozwój tego pojęcia w ostatnich kilkudziesięciu latach spowodował bowiem inflację jego znaczeń, prowadzącą do nieporozumień, błędnych skojarzeń i niesprawiedliwych osądów. Dotyczy to wymiaru wewnątrzkościelnego (wymiarów wewnątrzkościelnych), w którym przeciwnicy dążenia do jedności chrześcijaństwa stosują, często nieintencjonalnie, błędne rozumienie tego pojęcia, przypisujące mu lekceważenie podstaw teologicznych. Ale odnosi się również do

12 A Stępień, Racjonalność katolicyzmu, „Więź” 7-8(1960), s. 177. Dz. cyt. za: P. Dronszczyk, Światopogląd religiny jako przedmiot badań socjologicznych, „Śląskie Studia Historyczno-Teologiczne” 11(1978), s. 321. 
języka sfery publicznej, która często odrywa pojęcie ekumenizmu od jego chrześcijańsko-teologicznego fundamentu i nadaje mu znaczenie naiwnego inkluzywizmu, otwartości przechodzenia do porządku dziennego nad oczywistymi różnicami w odbiorze świata, nawet kosztem własnych przekonań. Najbardziej jaskrawym przykładem takiego błędnego rozumienia pojęcia ekumenizmu jest jego identyfikacja $\mathrm{z}$ dialogiem międzyreligijnym, przydarzająca się nie tylko laikom, ale niekiedy również teologom. W takim niepełnym bądź też nierzetelnym definiowaniu ekumenizmu łatwo jest zgubić właściwy jego sens i wręcz ośmieszyć jego przekaz.

$\mathrm{Z}$ pewnością więc światopogląd ekumeniczny nie zamyka się $\mathrm{w}$ definicjach popularnych obecnie na niektórych uniwersytetach w Stanach Zjednoczonych, gdzie pojęcie to służy określaniu postaw związanych z duchowością i religijnością i jest kategorią psychologiczną podlegającą badaniom. W jednej z takich definicji światopogląd ekumeniczny jest wskaźnikiem stopnia, w jakim dana osoba interesuje się różnymi religijnymi tradycjami, dąży do zrozumienia innych krajów i kultur, odczuwa silną więź z całą ludzkością, wierzy w dobroć wszystkich ludzi, akceptuje innych takimi, jakimi oni są i wierzy, że życia poszczególnych istot są wewnętrznie ze sobą powiązane i że miłość jest korzeniem wszystkich wielkich religii13. Światopogląd ekumeniczny jest więc traktowany jako pewna psychometryczna wartość, występując obok takich kategorii jak zaangażowanie w charytatywność, zaangażowanie religijne, konserwatyzm religijny/społeczny, równowaga wewnętrzna, sceptycyzm religijny i wiele jeszcze innych. Powyżej prezentowane określenie światopoglądu ekumenicznego sformułowane tak, aby mogło służyć jako psychometryczne narzędzie badające religijność czy duchowość danej jednostki nie jest z pewnością błędne. Jest jednak dalece niewystarczające, nieobejmujące zakresu znaczeń, jakie ono ze sobą niesie,

13 A.N. Bryant, Ecumenical Worldview Development by Gender, Race, and Worldview: A Multiple-Group Analysis

of Model Invariance, „Research in Higher Education” 5/52(2011), s. 465. 
podobnie jak psychologia nie jest w stanie wytłumaczyć całości istoty ekumenizmu.

Rozumienia ekumenizmu nie ułatwiają również różnice wyznaniowe. Wyznania i tradycje teologiczne różnie pojmują dążenia ekumeniczne, różnie stawiają teologiczne akcenty - kwestia Eucharystii jest tego najlepszym przykładem. Bardzo czytelnie zagadnienie różnic wyznaniowych prezentuje Światowa Rada Kościołów. Wyjaśniając znaczenie przymiotnika „ekumeniczny” autorzy programowego dokumentu „Ku wspólnemu rozumienieniu i wizji Światowej Rady Kościołów" (Towards a Common Undestanding and Vision of the World Council of Churches) z 1997 roku stwierdzają, że: „między Kościołami i organizacjami ekumenicznymi istnieje niepewność, dwuznaczność a nawet chaos dotyczący pytania »co oznacza ruch ekumeniczny«. Panuje zgoda co do tego, że termin »ekumeniczny« obejmuje dążenie do jedności chrześcijańskiej, wspólne świadectwo w globalnym dziele misyjnym i ewangelizacyjnym oraz zaangażowanie w diakonię i w promowanie sprawiedliwości i pokoju. Ale nie istnieje autorytatywna definicja tego pojęcia $\mathrm{i}$ jest ono $\mathrm{w}$ istocie stosowane w charakteryzowaniu szerokiego spektrum działań, idei i ustaleń organizacyjnych"14. Jednocześnie jednak ekumeniści ze Światowej Rady Kościołów przypominają najbardziej znaną definicję pojęcia „ekumeniczny”, sformułowaną przez Komitet Centralny (Central Committee) tej organizacji w 1951 roku: „słowo »ekumeniczny«, które pochodzi z greckiego terminu oznaczającego cały zamieszkały świat (oikoumene), jest stosowane właściwie do opisywania wszystkiego, co odnosi się do całego zadania, całego Kościoła, niesienia Ewangelii całemu światu"15.

Jak łatwo zauważyć, słowem kluczowym tej definicji jest „całość” odnosząca się do świata, Kościoła i zadania, które jest postawione przed wszystkimi chrześcijanami. Stwierdzenie to jest z jednej strony

14 Towards a Common Undestanding and Vision of the World Council of Churches, Geneva: World Council of Churches 1997, s. 12.

15 J. Hawkey, Mapping the Oikoumene. A Study of Current Ecumenical Structures and Relationships, Geneva: World Council of Churches 2005, s. 2. 
na tyle szerokie, że nie pozwala na zadowolenie się jakimkolwiek partykularyzmem, ale z drugiej strony na tyle precyzyjne, że wyraźnie przekazuje fundamenty ekumenizmu - Kościół, Ewangelia, jak i misja, z której nikogo nie można wykluczyć i z której realizacji nikt nie może być wykluczony. Jeśliby zestawić to określenie z przytaczaną powyżej definicją światopoglądu podaną przez Antoniego Stępnia, to łatwo ustalić, że kategoria całości jest w tym zestawieniu wspólnym mianownikiem (światopogląd jako spójny, całościowy obraz rzeczywistości). Kategoria ta pozwala również właściwie postawić różnice wyznaniowe, nie lekceważąc ich, ale też zwracając uwagę chociażby na fakt, że Ewangelia czy Kościół są specyficznie chrześcijańskie, odróżniające chrześcijan od reszty świata i w ten sposób łączące tych, dla których stanowią one kluczowe wartości. Dla ekumenisty punktem odniesienia jest właśnie taka „całość”, otwierając w ten sposób szeroki potencjał tożsamości chrześcijańskiej. Innymi słowy, najpierw odnosi się on do tego, co podobne i kształtuje wspólnotę opartą na wzajemnie przyjmowanych prawdach, dopiero potem, na gruncie tej wspólnoty, zajmuje się różnicami.

Ekumeniści zmuszeni budować apologetykę ekumenizmu, chroniąc go z jednej strony przed oskarżeniami różnorakich ruchów integrystycznych (funkcjonujących we wszystkich tradycjach wyznaniowych), albo też z drugiej przed naiwnym, często bezmyślnym irenizmem, mogą w kategorii światopoglądu ekumenicznego znaleźć w ten sposób użyteczne narzędzie samego działania ekumenicznego. Przede wszystkim bowiem, skoro światopogląd musi opierać się o pewien sposób interpretacji świata, to ekumenizm dostarcza przekonującego, dobrze ugruntowanego w wartościach i, co może najistotniejsze, pięknego w swej życzliwości paradygmatu postawy ludzkiej. Jest to wzorzec, który jawi się jako zgodny z naturą człowieka żyjącego w prawdzie o odkupieniu (usprawiedliwieniu) przez Chrystusa i w obietnicy zbawienia. Po drugie, skoro światopogląd jest definiowany nie tylko jako rezultat racjonalnej refleksji, ale również jako odzwierciedlenie woli i uczuć danej jednostki, w ekumenizmie można odnaleźć zarówno intelektualne źródło kształtowania swego obrazu świata, jak i przyciągające środowisko przynależności 
i identyfikacji. Ekumenizm jest więc bardzo mocnym czynnikiem światopoglądowotwórczym. Jeśliby odnieść się do omówionej powyżej teorii Diltheya, obejmuje bowiem trzy komplentarne źrodła swego powstania, właśnie intelekt, wolę i uczucie. Po trzecie, światopogląd ekumeniczny bardzo dobrze łączy się z innymi kategoriami, które przynależą ekumenizmowi, a więc z ruchem ekumenicznym, z ekumenicznym dialogiem i z ekumeniczną duchowością. Jak łatwo dostrzec, mogą być one uznane za czynniki tworzące przestrzeń jego realizacji. Szczególnie wyraźnie jest to widoczne, kiedy zestawi się pojęcie światopoglądu ekumenicznego z przedstawionymi poniżej definicjami ruchu ekumenicznego, dialogu ekumenicznego i ekumenizmu duchowego, sformułowanymi przez Sobór Watykański II. I tak, ruch ekumeniczny jest przez Ojców soborowych określony jako „działalność oraz przedsięwzięcia zmierzające do jedności chrześcijan, zależnie od różnych potrzeb Kościoła i warunków chwili’"16. Dialog rozumiany jest jako ,podjęty między odpowiednio wykształconymi rzeczoznawcami na zebraniach chrześcijan z różnych Kościołów czy Wspólnot, zorganizowanych w duchu religijnym, w czasie którego to dialogu każdy wyjaśnia głębiej naukę swej Wspólnoty i podaje przejrzyście jej znamienne rysy" "17. Wreszcie ekumenizm duchowy, który jest ujmowany jako „nawrócenie serca i świętość życia łącznie z publicznymi i prywatnymi modlitwami o jedność chrześcijan należy uznać za dusze całego ruchu ekumenicznego"18. Definicje te, w swym charakterze dość ścisłe, pomagają sformułować definicję samego światoglądu ekumenicznego, opartą o przytoczoną powyżej definicję Antoniego Stępnia. Światopogląd ekumeniczny mógłby więc być rozumiany jako przekonania tworzące całościowy obraz rzeczywistości, których źródłem jest wezwanie do jedności

${ }^{16}$ Dekret o ekumenizmie Unitatis Redintegratio (p. 4 i 8). Zob. w: Sobór Watykański II. Konstytucje, dekrety, deklaracje, Poznań: Wydawnictwo Pallotinum 1999.

17 Tamże.

18 Tamże. 
Chrystusa i które określają aktywną postawę jednostki będącej nośnikiem tego światopoglądu wobec Kościoła, chrześcijaństwa i świata.

\section{IV. Ś WIATOPOGLĄD EKUMENICZNY JAKO WYMIAR EKUMENICZNEJ MYŚLI SPOLECZNEJ}

Bardzo przekonujące wyjaśnienie znaczenia pojęcia światopoglądu ekumenicznego (ecumenical Weltanschauung) sformułował Paul Albrecht, wybitny ekumenista pracujący przez wiele lat w Światowej Radzie Kościołów. Jako jeden z nielicznych autorów, którzy posłużyli się tą kategorią przyjmował, że może ona być ujmowana jako „profetyczna wizja, chrześcijańska interpretacja duchowych, ideologicznych i społecznych wyzwań niesionych przez świat"19. Swoją intencję zilustrował przejmującym zdaniem pochodzącym z orędzia wystosowanego przez I Zgromadzenie Ogólne Światowej Rady Kościołów w Amsterdamie w 1948 r.: „Kiedy patrzymy się na Chrystusa, widzimy świat takim, jaki on jest" (When we look at Christ, we see the world as it is).

Albrecht nie rozwinął szerzej swojej interpretacji pojęcia światopoglądu ekumenicznego. Zasugerował jednak kierunek, który można byłoby określić w kategorii profetycznej roli chrześcijaństwa: „Zadanie duchowego czy profetycznego rozeznania nie jest wyłącznym powołaniem jakieś jednostki, czy też podjednostki Światowej Rady Kościołów. W pewnych czasach było podejmowane z wyobraźnią i z duchową spostrzegawczością; w innych dążenie do takiego komplementarnego rozumienia traciło swą moc" ${ }^{\prime 20}$. Dalej ekumenista dokonuje przeglądu najważniejszych inicjatyw podejmowanych przez organizacje i ludzi tworzących ruch ekumeniczny, które przyczyniły się do rozwoju ekumenicznej myśli społecznej.

19 P. Albrecht, Amsterdam to Vancouver - Where are we Today in Ecumenical Social Thought? „The Annual of the Society of Christian Ethics” 4 (1984), ss. 142 (137-170).

20 Ibid., s. 142n. 
Pojęcie światopoglądu ekumenicznego rozwija bowiem właśnie w perspektywie odpowiedzi na pytanie, czym jest ekumeniczna myśl społeczna. Dokonując jej całościowej i rzetelnej analizy, uznaje światopogląd ekumeniczny za jeden z jej wymiarów, wyróżniając poza tym dwa inne: pierwszy, który można określić jako eklezjalne zakorzenienie ekumenicznej myśli społecznej i drugi, mogący być ujęty jako jej historyczno-społeczne ukontekstowienie. Choć obie nazwy nie zostały sformułowane przez Albrechta, to jednak ich wyszczególnienie pozwala na dokonane pewnego podsumowania jego intencji. Jednocześnie krótkie rozwinięcie obu wymiarów lokuje pojęcie światoglądu ekumenicznego w kontekście przewidzianym przez autora i pomaga wydobyć sens zgodny z zamierzeniem genewskiego ekumenisty.

Wymiar eklezjalnego zakorzeniania ekumenicznej myśli społecznej oznacza, że ruch ekumeniczny wypracowuje ekumeniczną interpretację kwestii społecznych w uzgodnieniu z Kościołami, nie zaś jako jakąś oddzielną myśl organizacji ekumenicznych. Aby więc ekumeniczna myśl społeczna mogła być wiarygodna, musi być wyprowadzana z uzgodnionego nauczania Kościołów. Jej kształtowanie się jest dynamicznym procesem, w którym ruch ekumeniczny jakby koordynuje i relacjonuje dialog Kościołów dotyczący kwestii społecznych, wykorzystując go jednocześnie do stymulowania dążeń do jedności chrześcijan. Takie rozumienie znalazło swe szczególnie silne potwierdzenie w pierwszych dekadach ruchu, kiedy znaczna część refleksji dotyczyła zaangażowania społecznego, a we wspólnym działaniu widziano pretekst do bycia razem. Wystarczy tu przypomnieć pionierów ekumenizmu, a więc czy to ruch „Życie i Działanie”, czy też „Wiara i Ustrój, czy też początki funkcjonowania Światowej Rady Kościołów. Odnośnie do tej ostatniej, Albrecht przekonująco zauważa, że nigdy nie była jakimś wydziałem teologicznym, czy też stowarzyszeniem refleksji etycznej, raczej, że tworzyła miejsce, w którym Kościoły wspólnie badały tradycyjne chrześcijańskie myślenie o kwestiach społecznych i uzgadniały nowe podejścia. W ten sposób ruch ekumeniczny stawał się również twórczym, zwłaszcza, jeśliby uwględnić, że w refleksji brali udział również świeccy oraz 
przedstawiciele dyscyplin pozateologicznych, poza tym, odnosząc się do najbardziej aktualnych problemów społecznych i politycznych, ekumenizm potwierdzał swe praktyczne nakierowanie ${ }^{21}$.

Drugi wymiar ekumenicznej myśli społecznej zasadza się na ujmowaniu całego „mandatu” ekumenicznego, tak społecznego, jak i ewangelizacyjnego, misyjnego czy działań na rzecz jedności w ich specyficznych kontekstach społeczno-historycznych. Można tu powiedzieć, że ta obserwacja Albrechta zyskuje jeszcze bardziej na adekwatności, w miarę rozwoju ruchu ekumenicznego. Dla dzisiejszych ekumenistów bowiem coraz bardziej nienaruszalnym paradygmatem jest zbieganie się misji i ewangelizacji z działaniem na rzecz jedności ludzkości, z dążeniem do pokoju i sprawiedliwości. Paradygmat ten opiera się na założeniu, że znaczna część kwestii teologicznych, ewangelicznych czy misyjnych może być właściwie zrozumiała jedynie przy uwzględnieniu kontekstu społecznego ${ }^{22}$. Z drugiej strony należy tu wspomnieć, że kwestia integralności dążenia do jedności chrześcijan oraz troski o kwestie społeczno-polityczne była (i wciąż poniekąd jest) również głównym czynnikiem kontrowersji wewnatrz ruchu ekumenicznego. Rysują się w nim bowiem dwa podejścia. Według pierwszego, ekumenizm powinien skupiać się na materii teologicznej i na dążeniu do jedności chrześcijan ściśle w sensie jedności Kościoła, a w łączeniu tych działań z zaangażowaniem społecznym widzi się zagrożenie politycyzacją chrześcijaństwa. Według drugiego natomiast ekumenizm izolowany od działań na rzecz pokoju i sprawiedliwości, czy po prostu na rzecz dobra ludzkości (ekumenizm świecki), jest ograniczony i niewiarygodny.

$* * *$

Ilustracja koncepcji Albrechta bez wątpienia pomaga zrozumieć, czym jest światopogląd ekumeniczny. To, że ekumenista ze Światowej

${ }^{21}$ Ibid.

22 J.J. Ballor, Ecumenical Babel: Confusing Economy Ideology and the Church's Social Witness, Grand Rapids: Christian's Library Press 2010, s. 19. 
Rady Kościołów uczynił go jednym z wymiarów ekumenicznej myśli społecznej pozwala uchwycić potencjał tego pojęcia. Jest to potencjał spójnego obrazu rzeczywistości, wynikającego bowiem z wiary chrześcijańskiej i czerpiącego $\mathrm{z}$ wewnętrznej uniwersalności tej wiary. Jest to również potencjał wezwania do jedności, które ekumeniści przyjmują za swe zadanie-powołanie i które porządkuje ich hierarchię wartości. Ponadto, jest to potencjał wynikający z etyki Kazania na Górze, która nie pozwala obojętnie spoglądać na los bliźniego. Wreszcie, jest to potencjał ogromnej, globalnej społeczności, którą tworzy ruch ekumeniczny i która staje się bardzo ważnym czynnikiem refleksji i praktyki kształtującej postrzeganie jednostek tworzących tę wspólnotę. O światopoglądzie ekumenicznym bez wątpienia więc możemy mówić, a siła tego pojęcia dla danej jednostki może okazać się istotna w jeszcze bardziej świadomej i refleksyjnej identyfikacji z celami wspólnoty ekumenicznej i samego ekumenizmu.

\section{Streszczenie}

Na zbiór pojęć organizujących refleksję ekumeniczną składają się takie terminy jak duchowość ekumeniczna, dialog ekumeniczny, ekumeniczny ruch czy też ekumeniczna tożsamości. Rzadko jednak spotyka się z pojęciem światopoglądu ekumenicznego. Jest to o tyle zastanawiające, że pojęcie to zawiera w sobie wewnętrzny potencjał do tego, by pomagać poszczególnym ludziom zaangażowanym w działanie ekumeniczne w świadomej i refleksyjnej identyfikacji z wspólnotą ekumeniczną i jej celami. Artykuł stawia pytanie, jak można określić znaczenie światopoglądu ekumenicznego w świetle interdyscyplinarnej dyskusji nad terminem światopoglądu, dąży również do ustalenia, jak sam ekumenizm kształtuje światopogląd danej osoby. Przeprowadzone w tekście wnioskowanie oparte o prezentację koncepcji światopoglądu oraz jej zestawienie z syntetyczną analizą dokumentów i opracowań opisujących wpływ ekumenizmu na obraz świata pozwala na propozycję zdefiniowania światopoglądu ekumenicznego. Określa się go jako zespół przekonań tworzących całościowy obraz rzeczywistości, których źródłem jest Chrystusa wezwanie do jedności i które określają aktywną postawę jednostki będącej nośnikiem tego światopoglądu wobec Kościoła, chrześcijaństwa i świata. 
Słowa kluczowe: światopogląd, ekumenizm, Kościół, jedność

\begin{abstract}
The file of notions influencing ecumenical reflection consists of such terms as ecumenical spirituality, ecumenical dialogue, ecumenical movement or ecumenical identity. It seems to be however puzzling that the notion of ecumenical worldview is rather sparsely used and defined, even though it has its internal capability to help individuals who are involved in the ecumenical activities to reflexively identify with the ecumenical community and its purposes. Article asks the question of how could we understand the meaning of the ecumenical worldview, it also strives to ascertain how ecumenism itself causes a worldview of individuals. The presentation of the philosophical theory of worldview and its juxtaposition with the brief analysis of documents and ecumenical research describing influence of ecumenism on one's thinking about reality allow to suggest a definition of the ecumenical worldview. It is therefore defined as the group of convinctions causing a comprehensive picture of reality, of which source is the Christian calling to unity and which determines an active attitute of individuals who are subjects of this worldview towards Church, Christianity and world.
\end{abstract}

Abstract: worldview, ecumenism, Church, unity, Weltanschauung

\title{
Bibliografia
}

Albrecht P., Amsterdam to Vancouver - Where are we Today in Ecumenical Social Thought? „The Annual of the Society of Christian Ethics” 4 (1984), s. 137-170. Ballor J.J., Ecumenical Babel: Confusing Economy Ideology and the Church's Social Witness, Grand Rapids: Christian's Library Press 2010.

Bryant A.N., Ecumenical Worldview Development by Gender, Race, and Worldview: A Multiple-Group Analysis of Model Invariance, „Research in Higher Education" 5/52(2011), s. 460-479.

Campbell C., The Romantic Ethic and the Spirit of Modern Consumerism, Oxford: Blackwell 1987.

Cieciuch J1, Czym jest światopoglad? Filozoficzny kontekst psychologicznego pojęcia, „Psychologia Rozwojowa”10/2(2005), s. 147-159.

Dilthey W1, Groethuysen B1, Weltanschauungslehre. Abhandlungen zur Philosophie der Philosophie, Göttingen: Vandenhoeck \& Ruprecht 1991. 
Dronszczyk Pl, Światopogląd religiny jako przedmiot badań socjologicznych, „Śląskie Studia Historyczno-Teologiczne” 11(1978), s. 319-331.

Hawkey J1, Mapping the Oikoumene. A Study of Current Ecumenical Structures and Relationships, Geneva: World Council of Churches 2005.

Kuhn T.S., The Structure of Scientific Revolutions, Chicago: The University of Chicago Press 1970.

Leisegang H., Einführung in die Philosophie, Berlin-New York: Walter de Gruyter 1973.

Markowska M., Interpretacja jako rozumienie w ujęciu Wilhelma Diltheya, „Czasopismo filozoficzne" 2/2007, s. 58-74.

Olthuis J.H., On Worldviews, w: Marshall Paul, Griffioen Sander, Mouw Richard J. (red.), Stained Glass: Worldviews and Social Science, Lanham: University Press of America 1983, s. 26-40.

Sen A., Foreword, w: Polanyi Michael, The Tacit Dimension, Chicago: The University of Chicago Press 2009.

Sobór Watykański II. Konstytucje, dekrety, deklaracje, Poznań: Wydawnictwo Pallotinum 1999.

Stäuble G., Wissenschaftliche Weltanschauungen, „Aufklärung und Kritik - Zeitschrift für freies Denken und humanistische Philosophie" 1/2015, s. 188-194.

Towards a Common Undestanding and Vision of the World Council of Churches, Geneva: World Council of Churches 1997.

Wolters A.M., On The Idea of Worldview and Its Relation to Philosophy, w: Marshall Paul, Griffioen S., Mouw Richard J. (red.), Stained Glass: Worldviews and Social Science, Lanham: University Press of America 1983, s. 14-25. 